\title{
The proceduralisation of EU environmental legislation: international pressures, some victories and some way to go
}

Citation for published version (APA):

Eliantonio, M. (2015). The proceduralisation of EU environmental legislation: international pressures, some victories and some way to go. Review of European Administrative Law, 8(1), 99-123. https://doi.org/10.7590/187479815X14313382198377

Document status and date:

Published: 01/01/2015

DOI:

10.7590/187479815X14313382198377

Document Version:

Publisher's PDF, also known as Version of record

Document license:

Taverne

Please check the document version of this publication:

- A submitted manuscript is the version of the article upon submission and before peer-review. There can be important differences between the submitted version and the official published version of record.

People interested in the research are advised to contact the author for the final version of the publication, or visit the DOI to the publisher's website.

- The final author version and the galley proof are versions of the publication after peer review.

- The final published version features the final layout of the paper including the volume, issue and page numbers.

Link to publication

\footnotetext{
General rights rights.

- You may freely distribute the URL identifying the publication in the public portal. please follow below link for the End User Agreement:

www.umlib.nl/taverne-license

Take down policy

If you believe that this document breaches copyright please contact us at:

repository@maastrichtuniversity.nl

providing details and we will investigate your claim.
}

Copyright and moral rights for the publications made accessible in the public portal are retained by the authors and/or other copyright owners and it is a condition of accessing publications that users recognise and abide by the legal requirements associated with these

- Users may download and print one copy of any publication from the public portal for the purpose of private study or research.

- You may not further distribute the material or use it for any profit-making activity or commercial gain

If the publication is distributed under the terms of Article $25 \mathrm{fa}$ of the Dutch Copyright Act, indicated by the "Taverne" license above, 


\title{
The Proceduralisation of EU Environmental Legislation: International Pressures, Some Victories and Some Way to Go
}

\author{
Mariolina Eliantonio* \\ Assistant Professor at the Maastricht Center for European Law
}

\begin{abstract}
Despite the lack of an explicit procedural legal basis, the EU legislator has enacted several measures concerning access to justice and procedural rules applicable to environmental claims litigated before national courts. This paper examines the procedural provisions contained in the Environmental Liability Directive $(2004 / 35 / E C)$, and those contained in the two directives (2003/4/EC and 2003/35/EC) that have transposed the first and the second paragraphs of Article 9 of the Aarhus Convention as far as the law of the Member States is concerned. It also examines the initiatives currently undertaken at the EU level on the enactment of an Access to Justice Directive. The analysis will show how the current piecemeal approach has brought about significant advantages for the possibility of pursuing violations of EU environmental law by national authorities vis-à-vis the prior situation. This comes through the imposition of minimum requirements for rules on standing, costs, scope of review and remedies available in environmental claims. However, it will also be shown that the current level of proceduralisation of EU environmental legislation still exhibits clear shortcomings. These mainly derive from the lack of transposition of some of the requirements stemming from the Aarhus Convention through an Access to Justice Directive. This situation, which ought to be repaired soon, may ultimately impair the possibility for national courts to control violations of EU environmental law. This paper also reflects on the lessons which could be learnt from the process of proceduralisation of EU environmental legislation and specifically on whether the evolution of procedural provisions in the field of environmental law could be regarded as a model for other fields of law.
\end{abstract}

\section{Introduction}

Though it was first introduced by the Single European Act, it was with the Maastricht Treaty that EU environmental policy was significantly strengthened. Environmental protection was made an explicit aim of the (then) European Community and the Council was empowered to adopt environmental measures by qualified majority voting, rather than the former unanimity vote that was required. Since the entry into force of the Treaty in 1993, EU activity

* DOI $10.7590 / 187479815 X_{14313382198377}$ 
in the field of environmental policy has accelerated, resulting in an impressive body of legislation. Neither the Maastricht Treaty, nor any subsequent Treaty amendment, however, contains any explicit legal basis concerning the enforcement of EU environmental law or the enactment of procedural provisions to this end.

From the lack of any express 'procedural legal basis', it cannot, however, be concluded that the environmental policy field is devoid of any provisions of a procedural nature - specifically of provisions concerning access to court and judicial proceedings. ${ }^{1}$

With over 200 pieces of legislation (as the Commission itself indicates) ${ }^{2}$ looking for 'procedural provisions' in EU environmental legislation is certainly a 'needle-in-the-haystack' enterprise. However, upon a closer look, it appears that there are essentially two main 'streams' of proceduralisation, one stemming from the Environmental Liability Directive 2004/35/EC, and the other coming from the two directives (i.e. Directive 2003/4/EC and Directive 2003/35/EC) which have transposed the first and the second paragraphs of Article 9 of the Aarhus Convention as far as the law of the Member States is concerned.

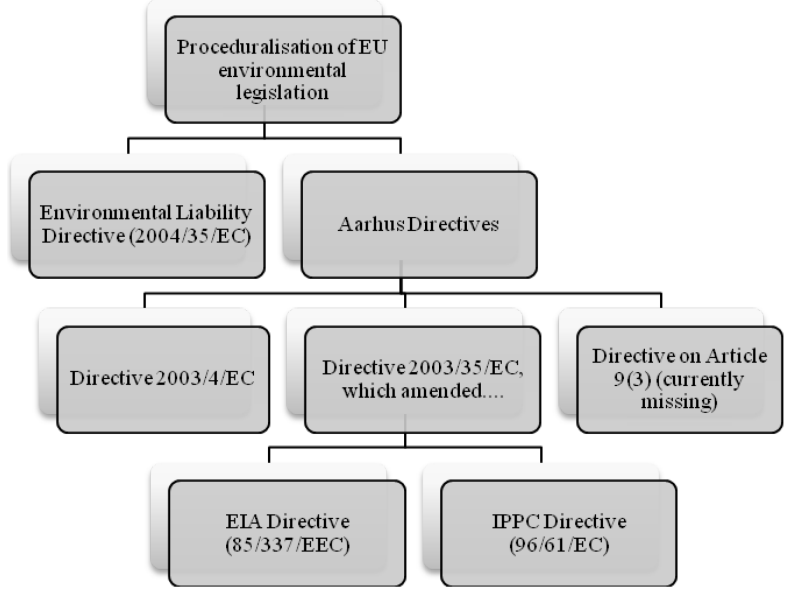

Figure 1: Schematic Overview of the Proceduralisation of EU Environmental Legislation

1 Please note that, for the purposes of this paper, only provisions affecting the procedural law of the Member States will be examined, with the exclusion, therefore, of procedural rules applicable before the EU judiciary.

2 http://ec.europa.eu/environment/ legal/law/. 
After an introduction to the procedural provisions contained in the Aarhus Convention, this paper will examine the three above mentioned pieces legislation as to their rationale, aim and content, as well as the initiatives currently undertaken at EU level on the enactment of an Access to Justice Directive. The analysis will show how the current piecemeal approach has brought about significant advantages for the possibility of pursuing the violations of EU environmental law by national authorities vis-à-vis the prior situation through the imposition of minimum requirements for rules on standing, costs, scope of review and remedies available in environmental claims. However, it will also be shown that the current level of proceduralisation of EU environmental legislation still exhibits clear shortcomings. These mainly derive from the lack of transposition of some of the requirements stemming from the Aarhus Convention through an Access to Justice Directive. This situation, which ought to be repaired soon, may ultimately impair the possibility for national courts to control the violations of EU environmental law. At the end of this paper, a conclusion will be drawn as to the 'state of proceduralisation' of EU environmental legislation as well as on the lessons which could be learnt from the process of proceduralisation of EU environmental legislation and specifically on whether the evolution of procedural provisions in the field of environmental law could be regarded as a model for other fields of law.

\section{The 'Aarhus Directives'}

\subsection{The Aarhus Convention}

The Aarhus Convention ${ }^{3}$ is a UN Convention which was developed within the UNECE (United Nations Economic Commission for Europe) and is structured around three main pillars: access to information, public participation, and access to justice in environmental matters aimed at promoting environmental democracy. The Convention was adopted by the European Community on 17 February 2005 by Decision $2005 / 370 / \mathrm{EC}^{4}$ and is, therefore,

3 United Nations Economic Commission for Europe, Convention on Access to Information, Public Participation in Decision-Making and Access to Justice in Environmental Matters, www.unece.org/fileadmin/DAM/env/pp/documents/cep43e.pdf. The EU and all EU Member States are contracting parties to the Convention.

4 Council Decision 2005/370/EC of 17 February 2005 on the conclusion, on behalf of the European Community, of the Convention on access to information, public participation in decision-making and access to justice in environmental matters [2005] OJ L124/1. 
binding upon the EU as such, as well as the Member States when they act within the scope of application of EU law. ${ }^{5}$

The access to justice pillar, which is of interest for the purposes of this paper, is contained in Article 9 of the Convention. This provision, in turn, provides for a tripartite sub-division with an umbrella requirement.

Article 9(1) contains an access to justice obligation with respect to the alleged violation of first pillar of the Convention, access to information. Specifically, it requires contracting parties to ensure that any person who considers that his or her request for information has been ignored, wrongfully refused (whether in part or in full), inadequately answered, or otherwise not dealt with in accordance with the requirements of the Convention itself, has access to a review procedure before a court of law or another independent and impartial body established by law. In addition, the provision requires that where a party provides for judicial review before a court of law, it must also offer access to a 'free' or 'inexpensive' and 'expeditious' procedure under law for the purposes of either reconsideration by a public authority or review by an independent and impartial body other than a court of law.

Article 9(2) mandates certain requirements for access to justice with respect to situations where the second pillar of the Convention (public participation) is at stake. This article provides that the contracting parties should ensure that concerned members of the public with (1) a sufficient interest; or (2) maintaining impairment of a right (where the administrative procedural law of a state requires this as a precondition), have access to a review procedure to challenge the substantive and procedural legality of decisions concerning activities subject to the public participation requirements contained in Article 6 of the Convention itself. Article 9(2) covers projects which can have a significant environmental impact.

Article 9(3) provides for a general access to justice obligation, which the Convention refers to as 'access to administrative or judicial procedures to challenge acts and omissions by private persons and public authorities which contravene provisions of [...] national law relating to the environment'. ${ }^{6}$

5 It should also be added that, since all the Member States have ratified the Aarhus Convention, this international instrument is binding on them outside the scope of application EU law as well. However, in such cases, the effect of the Convention within the legal order of the Member States is dependent upon their constitutional orders.

6 See further on the Aarhus Convention and Article 9 specifically, M. Pallemaerts (ed), The Aarhus Convention at Ten - Interactions and Tensions between Conventional International Law and EU Environmental Law (Europa Law Publishing 2011); L. Lavrysen, 'The Aarhus Convention: Between Environmental Protection and Human Rights', in: P. Martens, M. Bossuyt, M. Rigauxan \& B. Renauld, Liber amicorum Michel Melchior (Anthemis 2010), p. 663; J. Jendroska, 'Accès à la justice: remarque sur le statut juridique et le champ des obligations 
The umbrella provision of the access to justice pillar of the Aarhus Convention is contained in paragraph 4 of the same Article 9 . This requires contracting parties to provide adequate and effective remedies for violations of environmental law, including injunctive relief and to ensure that judicial review procedures be fair, equitable, timely and not prohibitively expensive.

\subsection{The Access to Information Directive}

Article 9(1) of the Aarhus Convention has been transposed through Directive 2003/4/EC, the so-called 'Access to Information Directive'?

As far as procedural provisions are concerned, the Directive contains an access to justice requirement which follows directly from the Aarhus Convention, although to an extent it offers even more protection than that mandated by the Convention. In particular, while the Convention foresees the possibility to a contracting party of offering a single, non-judicial, avenue to applicants, Article 6 of Directive 2003/4 requires Member States to secure two routes for applicants.

Firstly, according to Article 6(1), Member States should ensure that applicants have access to an administrative review procedure. This procedure should be expeditious and either free of charge or inexpensive, and should be carried out either by the same authority concerned by the information request or another public authority, or by an independent and impartial body established by law.

Secondly, Article 6(2) provides that Member States have an obligation to ensure that an applicant has access to a review procedure before a court of law or another independent and impartial body established by law, in which the acts or omissions of a public authority (such as where the applicant's request for information has been ignored, wrongfully refused, inadequately answered or otherwise not dealt with in accordance with the provisions of the Directive)

de la convention d'Aarhus dans le contexte de l'Union Européenne' [2009] Revue Juridique de l'Environnement, Special Issue, p. 31; T. Danwitz, 'Aarhus Konvention: Umweltinformation, Öffentlichkeitsbeteiligung, Zugangzu den Gerichten' [2004] Neue Zeitschrift Fuer Verwaltungsrecht, p. 272; P. Oliver, 'Access to Information and to Justice in EU Environmental Law: the Aarhus Convention' [2013/5] Fordham Journal of International Law, p. 1423; J. Maurici, 'The Influence of the Aarhus Convention on EU Environmental Law: Part I' [2013] Journal of Planning and Environmental Law, p. 1469 and J. Maurici, 'The Influence of the Aarhus Convention on EU Environmental Law: Part II' [2014] Journal of Planning and Environmental Law, p. 181.

7 Directive 2003/4/EC of the European Parliament and of the Council of 28 January 2003 on public access to environmental information and repealing Council Directive 90/313/EEC [2003] OJ L41/26. 
can be reviewed. Furthermore, according to the Directive, Member States have the option to provide that third parties incriminated by the disclosure of information may also have access to legal recourse.

This set of provisions can be considered as great progress given the former EU legislation in this area (i.e. Directive 90/313/EEC on the freedom of access to information). ${ }^{8}$ This instrument provided a short article dealing with remedies where an applicant was dissatisfied with a public authority's response (or lack of response) to a request for access to information. Article 4 of the original Directive provided that the usual administrative and/or judicial remedies available within the national legal system applied in such situations. This provision thus left the Member States free to determine the format and scope of the relevant remedies. The review of the operation of the Directive published by the Commission in 2000 found (unsurprisingly) that Member States adopted diverse approaches to review procedures. Only some Member States provided for recourse to judicial procedures, while others established an administrative review procedure with the possibility of subsequent judicial review. ${ }^{9}$

For the purposes of the current analysis, what has to be noted is that the Access to Information Directive, while leaving Member States free to decide whether access should be given to civil or administrative courts, does require them to create a judicial review avenue (where it was not otherwise provided in the national legislation) for claims concerning allegedly ill-treated requests of access to environmental information. It also grants standing in judicial review procedures to those natural or legal persons whose access request has not been dealt with in accordance with the Directive itself, in line with what prescribed by Article 9(1) of the Aarhus Convention. Thus, Member States are prevented from setting any requirement to the effect that an individual needs to show the existence of an affected interest or the impairment of a right to have access to court.

As far as the scope of review is concerned, the Access to Information Directive provides that courts should be able to consider whether the access request

8 See Article 5 of the former Directive 90/313/EEC on the freedom of access to information on the environment [1990] OJ L158/56, which required in rather general terms that Member States provide 'judicial or administrative review' of any decision concerning an access to information request. M. Hedemann-Robinson, 'EU Implementation of the Aarhus Convention's Third Pillar: Back to the Future over Access to Environmental Justice? Part 2' [2014/4] European Energy and Environmental Law Review, p. 152. See also A. Ryall, 'Implementation of the Aarhus Convention through Community Environmental Law’ [2004] Environmental Law Review, p. 274.

9 Report from the Commission to the Council and the European Parliament on the experience gained in the application of Council Directive 90/313/EEC on freedom of access to information on the environment $\operatorname{COM}(2000) 400$ final, 29 June 2000. 
was 'ignored, wrongfully refused or inadequately answered or otherwise not dealt with' in accordance with the provisions of the Directive itself. This means that the court's review can cover both procedural and substantive errors in the handling of the access request. In this way, although the Directive (or the Aarhus Convention) does not explicitly mention that the scope of review should extend to the 'procedural and substantive legality' of a decision, this same scope of review can be considered implied in the wording of Article 6(2), thus streamlining this procedural aspect with the requirements of the Public Participation Directive.

Moreover, while the Directive does not prescribe a clear set of remedies nor incorporate the requirement that remedies should be 'adequate and effective' (as required by Article 9(4) of the Aarhus Convention), it does provide, in Article $6(3)$, that the decision of the court concerning the access request shall be binding on the public authority holding the information.

Finally, regrettably, the Directive does not provide for procedural provisions on the costs of judicial review procedures, despite the requirement of Article 9(4) of the Aarhus Convention (and the 'not prohibitely expensive' requirement contained therein) to procedures taken under Article 9(1) of the Convention.

However, both of these omisssions do not render the Aarhus requirements inapplicable, as the case law of the Court of Justice of the European Union has made it clear that the EU legislation implementing the Aarhus Convention must be interpreted in line with the latter. ${ }^{10}$ The same conclusion can be reached by taking into account in particular the express reference in the preamble that EU law provisions 'must be consistent with' the Convention."

10 Case C-115/og Bund für Umwelt und Naturschutz Deutschland, Landesverband Nordrhein-Westfalen eVv. Bezirksregierung Arnsberg [2011] ECR I-03673, para. 41.

${ }_{11}$ Recital 5 of the preamble to the Access to Information Directive 2003/4. 
The Figure below provides a schematic overview of the procedural areas affected by the Access to Information Directive and the requirements set therein.

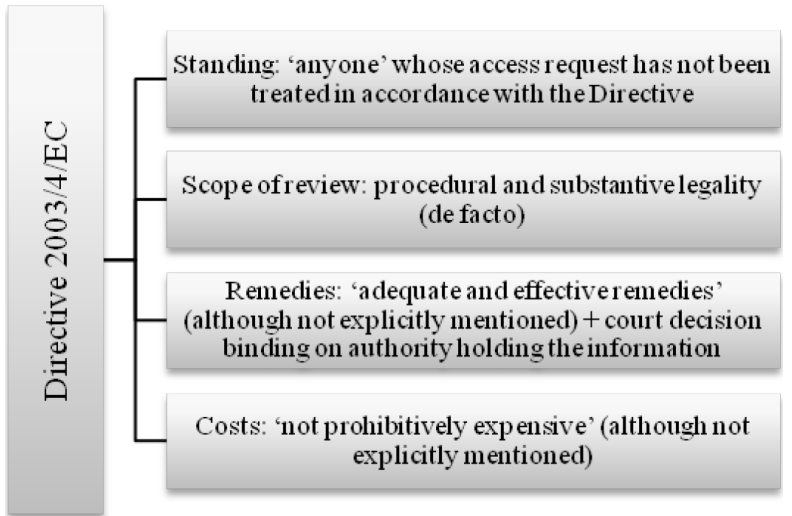

Figure 2: Schematic Overview of Procedural Areas Affected by the Access to Information Directive

\subsection{The Public Participation Directive}

With a view to aligning Member States' legislation with Article 9 (2) and (4) of the Convention, the EU has enacted Directive 2003/35/EC, ${ }^{12}$ which concerns public participation in relation to the authorisation of specific industrial activities affecting the environment.

With regard to procedural provisions, this Directive has inserted Article 10a into the text of Directive 85/337/EC (the Environmental Impact Assessment (EIA) Directive) ${ }^{13}$ and Article 15 a into the text of Directive 69/61/EC (the Integ-

12 Directive 2003/35/EC of the European Parliament and of the Council of 26 May 2003 providing for public participation in respect of the drawing up of certain plans and programmes relating to the environment and amending with regard to public participation and access to justice Council Directives 85/337/EEC and 96/61/EC [2005] OJ L156/17. On this point, see B. Dette, 'The Aarhus Convention and Legislative Initiatives for its Implementation' in: T. Ormond, M. Führ and R. Barth (eds), Liber amicorum Betty Gebers (Lexxion 2006), p. 63. Further on the interplay between the Aarhus Convention and EU law see J. Ebbeson, 'Access to Justice at the National Level - Impact of the Aarhus Convention and European Union Law' in: Marc Pallemaerts (ed), The Aarhus Convention at Ten - Interactions and Tensions between Conventional International Law and EU Environmental Law (Europa Law Publishing 2011), p. 247.

13 Directive $85 / 337 /$ EEC on the assessment of the effects of certain public and private projects on the environment [1985] OJ L175/40. 
rated Pollution Prevention and Control (IPPC) Directive).${ }^{14}$ Subsequently, these provisions have been transferred to the most recent versions of the EIA Directive and the IPPC Directives without any changes, and they are currently to be found in Article 11 of Directive 2011/92/EU ${ }^{15}$ on the assessment of certain public and private projects on the environment and Article 25 of the recast Directive 2010/75/EU on industrial emissions. ${ }^{16}$

These provisions are an almost an exact replicate of Articles 9(2) and (4) of the Aarhus Convention.

These articles, like Article 9(2) of the Convention, propose two models of access to justice. While leaving Member States free to provide access to civil or administrative courts, they do require them to provide access to a review procedure wherein qualified members of 'the public concerned' can challenge 'the substantive or procedural legality' of decisions that are subject to the participation requirements mandated by the said Directives. However, the provisions leave the parties free to decide whether to allow standing for the "public concerned' only where the claimant can maintain the impairment of a right or when it is able to show a sufficient interest.

Just like the Aarhus Convention, the Public Participation Directive does not directly define what is meant with the standing tests proposed: instead, Articles $10 \mathrm{a}$ and 15 a state that what constitutes a sufficient interest and impairment of a right shall be determined by the Member States, subject, however, to two conditions. Firstly, 'sufficient interest' and 'impairment of a right' should be interpreted consistently with the objective of giving the public concerned wide access to justice. Secondly, any NGO promoting environmental interests and meeting any requirements under national law shall be deemed as capable of showing sufficient interest. Such organisations shall also be deemed to have rights capable of being impaired in a legal system that has opted for a rightsbased approach.

14 Council Directive 96/61/EC of 24 September 1996 concerning integrated pollution prevention and control [1996] OJ L257/26.

15 Directive 2011/92/EU of the European Parliament and of the Council of 13 December 2011 on the assessment of the effects of certain public and private projects on the environment [2012] OJ L26/1. Please note that the latest amendments to the EIA Directive brought by Directive 2014/52/EU did not touch Article 11. Directive 2014/52/EU of the European Parliament and of the Council of 16 April 2014 amending Directive 2011/92/EU on the assessment of the effects of certain public and private projects on the environment [2014] OJ L124/1.

16 Directive 2010/75/EU of the European Parliament and of the Council of 24 November 2010 on industrial emissions (integrated pollution prevention and control) [2010] OJ L334/17. 
Finally, just like the Aarhus Convention, these provisions require the national review procedures to be 'fair, equitable, timely and not prohibitively expensive'.

While limited in scope to only claims concerning activities subject to the public participation requirements contained the Directive (which cover mostly industrial activities having significant environmental impact), the Public Partipation Directive is an important milestone in the proceduralisation process of EU environmental law because of the different procedural areas it is capable of affecting.

First of all, while respectful of national differences with regard to standing rules, and leaving Member States free to choose between a right-based or an interest-based approach, the Directive does afford a certain preferential status to NGOs in view of the essential role they play in the enforcement of environmental law. This approach has put pressure on some legal systems, as is evidenced by the case law of the CJEU. In the Djurgården case, ${ }^{17}$ the CJEU ruled that a requirement of Swedish law that an NGO had to have at least 2000 members to have access to court did not ensure a 'wide access to justice' and did not comply with the standards set by Directive 2003/35/EC. The hardest blow to national rules on standing was, however, given by the CJEU to the German legal system. A few years after the Djurgården case, the CJEU decided on another preliminary reference, this time sent by a German court and concerning the German transposition of Directive 2003/35/EC. ${ }^{18}$ According to the contested German provisions, non-governmental organisations promoting environmental protection were granted standing before a court, in an action contesting a decision authorising projects likely to have 'significant effects on the environment' for the purposes of Article 1(1) of the EIA Directive, only where they could show the potential infringement of a rule which confers individual rights. However, in the proceedings before the national court, the NGO was not maintaining the impairment of an individual right. Instead, it was seeking to challenge an administrative measure in so far as it authorised activities which, while not violating an individual's subjective rights, were likely to harm the

Case C-263/08 Djurgården-Lilla Värtans Miljöskyddsförening v. Stockholms kommun genom dess marknämnd [2009] ECR I-09967. For a comment on this case, see A. Ryall, 'Comment to Djurgården' [2010] Common Market Law Review, p. 1511.

18 Case C-115/o9 Bund für Umwelt und Naturschutz Deutschland, Landesverband Nordrhein-Westfalen eV v. Bezirksregierung Arnsberg (intervening party: Trianel Kohlekraftwerk Lünen GmbH \& Co. KG) [2001] ECR I-3673, commented by M. Eliantonio, Case C-240/09 Lesoochranárske zoskupenie VLK v. Minister stvozivotného prostredia Slovenskej republiky, Judgment of the Court of Justice (Grand Chamber) of 8 March 2011 , nyr, and Case C-115/o9 Bund für Umwelt und Naturschutz Deutschland, Landesverband Nordrhein-Westfalen eV v. Bezirksregierung Arnsberg (intervening party: Trianel Kohlekraftwerk Lünen GmbH \& Co. KG) Judgment of the Court of Justice (Fourth Chamber) of 12 May 2011, nyr., Common Market Law Review (2012), p. 767 (with further references contained therein). 
environment as such. As the Advocate General Sharpston put it, '[I]n that sense, it may be said that the environmental NGO [was] seeking to act on behalf of the environment itself ${ }^{19}$ According to the applicable procedural rules, therefore, the NGO could not be granted standing: the question posed by the German judge was thus whether the German transposition of Directive 2003/35/EC could be considered to be in line with the requirement of 'wide access to justice' mandated by the Directive and the Aarhus Convention.

The Court of Justice held that whichever option a Member State chose for the admissibility of an action (i.e. a right-based or an interest-based model), environmental protection organisations were entitled, pursuant to Article 10a of the EIA Directive, to have access to a review procedure before a court of law or another independent and impartial body established by law, to challenge the substantive or procedural legality of decisions, acts or omissions covered by that Article. This possibility had to be guaranteed, according to the Court, even where the rules relied on protected only the interests of the general public and not the rights or interests of individuals. The German rules which prevented such challenges were therefore considered in breach of Article 10a.

Secondly, albeit in rather vague terms, the Public Participation Directive sets some limits to the rules on costs applicable in the national legal systems. While the Directive (like Article 9(4) of the Aarhus Convention) does not require Member States to provide 'free or inexpensive' procedures (as is instead the case for administrative procedures based under the Access to Information Directive), it does require procedures not to be 'prohibitively expensive'. This aspect is linked to the overall aim of the Aarhus Convention in that excessive costs of legal proceedings could effectively operate as a deterrent for members of the public and NGOs from seeking recourse through a judicial review mechanism. This requirement in the Public Participation Directive has in turn been interpreted in some instances by the CJEU, which has sanctioned some Member States for failing to fully comply with the Directive.

In Commission v. Ireland the Court had to rule on the implementation of the obligation that procedures should not be prohibitively expensive into Irish law. ${ }^{20}$ According to the Court the requirement does not prevent courts from making cost orders addressed to unsuccessful litigants. ${ }^{21}$ However, a mere practice by courts aimed at reducing or at not imposing costs on litigants with insufficient

19 Opinion of AG Sharpston in Case C-115/o9 Bund für Umwelt und Naturschutz Deutschland, para. 1.

20 C-427/07 Commission of the European Communities v. Ireland [2009] ECR I-6277.

21 C-427/07 Commission of the European Communities v. Ireland [2009] ECR I-6277, para. 92. 
means was not seen as sufficient implementation of the Public Participation Directive.

Furthermore, the CJEU addressed the costs regime of the United Kingdom in Edwards ${ }^{22}$ and Commission v. $U K,{ }^{23}$ and it held that the discretionary practice of the UK courts to award protective cost orders contravened the requirements of the Public Participation Directive. In Edwards, the CJEU specifically mentioned that a legal cost assessment by a national court should not be carried out solely on the basis of the financial situation of the person concerned but must also be based on an objective analysis of the amount of the costs, particularly since, members of the public and associations are naturally required to play an active role in defending the environment. Therefore, in the opinion of the Court, the cost of proceedings must neither exceed the financial resources of the person concerned nor appear, in any event, to be objectively unreasonable. ${ }^{24}$ In Commission v. UK, the CJEU tackled instead the costs during interim proceedings and specifically the UK system of cross-undertaking in damages, the purpose of which is to ensure that the party subject to an interim injunction is compensated if the court subsequently decides against the party requesting the injunction and the other party has in the meantime suffered a loss as a consequence of complying with the injunction. The Court considered that this system was not sufficiently clear as to comply with the 'not prohibitively expensive' requirement. ${ }^{25}$

Thirdly, while not mandating the specific depth of review, the Public Participation Directive requires national procedural rules to allow courts to review the 'substantive and procedural legality' of decisions allegedly taken in violation of the participatory requirements mandated by the Directive itself. This requirement is rather vague and allows for quite some discretion on the part of the Member States. However, it has also been given some flesh by the case law of the CJEU, which stated that, while Member States can limit access to court to challenge procedural defects which have no conceivable influence on the final ronment Agency and Others [2013] [nyr].

23 Case C-530/11 Commission v. United Kingdom [2014] [nyr]; Case C-427/07 Commission of the European Communities v. Ireland.

24 Case C-260/11 The Queen, on the application of David Edwards and Lilian Pallikaropoulos v. Environment Agency and Others [2013] [nyr], para. 40.

25 Case C-530/11 Commission v. United Kingdom [2014] [nyr]; Case C-427/07 Commission of the European Communities v. Ireland, para. 69 and 71. 
administrative decision, they cannot put on the applicant the burden of proof that a procedural defect had an impact on the final decision. ${ }^{26}$

Finally, although the Aarhus Convention obliges the Contracting Parties to provide for adequate and effective remedies, this requirement cannot be found in the Public Participation Directive. However, for the same reason as highlighted above with regard to the Access to Information Directive, this requirement should still be considered as applicable in the EU legal order as, according to the case law of the CJEU, EU legislation implementing the Aarhus Convention must be interpreted in line with the latter. The CJEU has partially intervened to fill this gap by relying on earlier case law on this issue ${ }^{27}$ and stating that, despite the absence of national procedural rules to this effect, national courts are able to avail themselves of interim measures to prevent environmental damage (a requirement which, although explictly present in Article 9(4) of the Aarhus Convention, has also (inexplicably) not been incorporated in Directive $2003 / 35 / \mathrm{EC}) .^{28}$

The Figure below provides a schematic overview of the procedural areas affected by the Public Participation Directive and the requirements set therein.

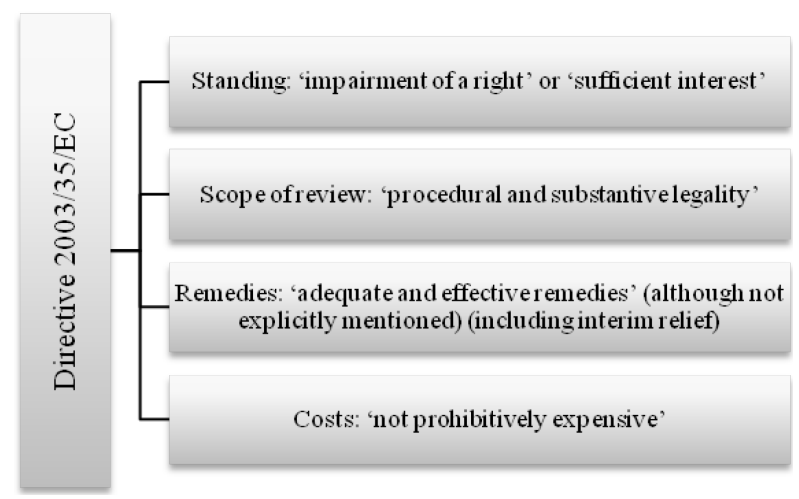

Figure 3: Schematic Overview of Procedural Areas Affected by the Public Participation Directive

26 Case C-72/12 Gemeinde Altrip and Others v. Land Rheinland-Pfalz [2013] [nyr]. For a comment on this case, specifically with regard to the German legal system, see T. Bunge, 'Rechtsfolgen von Verfahrensfehlernbei der Umweltverträglichkeitsprüfung' [2014] Natur und Recht, p. 305.

27 Case C-213/89 Factortame and Others [1990] ECR I-2433, para. 21, and Case C-432/05 Unibet [2007] ECR I-2271, para. 67.

28 Case C-416/10 Jozef Križan and Others v. Slovenská inšpekcia životného prostredia [2013] [nyr], para. 105-110. 


\subsection{The (Future?) Access to Justice Directive}

The Public Participation Directive was only meant to transpose Article 9(2) of the Aarhus Convention. As a consequence, the procedural provisions introduced by this Directive only affect procedural rules which are to be applied in a claim concerning an allegation that the provisions of the EIA Directive or the IPPC Directive have been violated. They do not apply, therefore, to environmental measures taken outside the scope of these Directives, such as in the case of measures taken for the protection of an endangered species under the Habitats Directive or permits to discharge waste water. A more general provision on access to justice covering all environmental matters, which would transpose the requirements of Article 9(3) of the Aarhus Convention, is currently lacking.

The Commission had originally presented a Proposal for a Directive of the European Parliament and of the Council on access to justice in environmental matters ${ }^{29}$ (which would give effect to Article 9(3) of the Convention). But, the Directive was never adopted (and was ultimately withdrawn in May 2014) 30 $^{30}$ since 'Member States remained unconvinced that legislative action at EU level was needed to implement Article 9(3)', ${ }^{31}$ and that the proposal was overly intrusive into the national judicial systems. ${ }^{32}$

Since 2012, however, the Commission has put the issue of the transposition of the third paragraph of Article 9 of the Aarhus Convention back on the legislative agenda, and for these purposes, committed some studies. ${ }^{33}$ In principle this goal could, according to the Commission, be achieved in several ways. Firstly, the Commission had proposed the possibility of working on a new proposal for a directive on access to justice, which would take the legal situation in the Member States and the recent case law of the CJEU into account, and essentially mirror what has been done in Directive 2003/35/EC with regard to Article 9(2). Alternatively, the Commission had proposed three other options: first, to reiterate the 'old' proposal which has been stalled in the Council since

29 Proposal for a Directive of the European Parliament and of the Council on access to justice in environmental matters, $\operatorname{COM}(2003) 624$ final, 24 October 2003.

Withdrawal of obsolete Commission proposals [2014] OJ C-153/03.

31 European Commission, Explanatory Consultation Document, 2, http://ec.europa.eu/environment/ consultations/pdf/access.pdf.

32 European Commission, Roadmap, Commission initiative on Access to justice in environmental matters at Member State level in the field of EU environment policy, p. 1, available at http://ec.europa.eu/smart-regulation/impact/planned_ia/docs/2013_env_o13_access_ to_justice_en.pdf.

33 European Commission, The Aarhus Convention - 2012/2013 access to justice studies, http://ec.europa.eu/environment/aarhus/access_studies.htm. 
$2003 ;{ }^{34}$ second, to use soft law instruments to promote collaboration between national courts, possibly supplemented by Commission guidelines explaining the significance and implications of the case law; or, third, to use the infringement proceedings as a tool to promote compliance with the requirements of the CJEU's case law. The study undertaken to compare these options shows a preference for a legislative option, and deems it more effective to achieve the aims set out in Article 9(3) and therefore ensure an effective enforcement of EU environmental law. In particular, the study considers that the 'soft law' option would leave national differences intact. It also notes that it would not provide any incentive for Member States to comply with CJEU case law, and that the infringement proceedings option is too time and resource consuming, with the result that it does not ensure the necessary uniformity. Furthermore, none of these options are considered to ensure a sufficient level of legal certainty and a level playing field for NGOs throughout the EU. ${ }^{35}$

At the same time, the Commission has launched a series of initiatives (including a public consultation) $)^{36}$ in order to prepare the ground for possible legislative action. At the final stage of its internal evaluation of possible future moves, the Commission has produced a roadmap document for the purposes of an impact assessment review. ${ }^{37}$ Currently, the roadmap is subject to ongoing review and awaiting formal approval..$^{8}$

In the meantime, the CJEU has intervened in a preliminary question sent by a Slovakian court and, while holding that Article 9(3) of the Aarhus Convention does not have direct effect, it did require national courts to interpret national law to the fullest extent possible in such a way as to provide access to nongovernmental organisations alleging the violation of EU environmental law. ${ }^{39}$

Given the legal uncertainty generated by the lack of transposition of Article 9(3) and the unsuitability of the alternative mechanisms (i.e. the use of soft law for streamlining national procedural standards or of infringement proceedings),

34 For the differences between these two options see J. Darpö, Effective Justice? Synthesis report of the study on the Implementation of Articles 9.3 and 9.4 of the Aarhus Convention in Seventeen of the Member States of the European Union [2012], p. 24.

35 Ibid., p. 23. Please note that this preference seems to be shared also by those who participated in the public consultation launched by the Commission on this theme. http://ec.europa.eu/ yourvoice/ipm/forms/dispatch? userstate=DisplayPublishedResults\&form=A2JUST (see in particular question $12(\mathrm{c}))$.

${ }_{3} 6$ http://ec.europa.eu/environment/aarhus/consultations.htm.

37 http://ec.europa.eu/smart-regulation/impact/planned_ia/docs/2013_env_o13_access_ to_justice_en.pdf.

38 http://ec.europa.eu/smart-regulation/impact/planned_ia/roadmaps_2014_en.htm\#ENV.

39 C-240/o9 Lesoochranárskezoskupenie VLK v. MinisterstvoživotnéhoprostrediaSlovenskejrepubliky [2011] ECR I-01255. 
it is certainly desirable to set criteria for NGO standing at the EU level; different procedural rules may create divergent results when national courts apply the same EU environmental provision. Furthermore, as the Commission indicates, the current state of uncertainty may create market distortions of competition and uncertainty for investments; failure to maximise the benefits of environmental legislation and potential non-compliance with EU law; and a growing number of complaints not being handled at national level and, therefore, flooding the Commission. ${ }^{40}$

\section{The Environmental Liability Directive}

Another source of procedural provisions in EU environmental legislation is Directive 2004/35/EC ${ }^{41}$ (the Environmental Liability Directive), whose principal aim is to establish, in accordance with the 'polluter pays' principle, a legal framework for Member States which would ensure that operators carrying out certain industrial activities and causing actual or threatened damage to the environment are held accountable. ${ }^{42}$

While focusing mostly on the role which public authorities are to play in ensuring that operators take the appropriate preventive or remedial actions with respect to a potential or actual environmental damage, Articles 12 and 13 of the Directive contain specific procedural provisions directed at private entities, and specifically NGOs, in their enforcement role.

In particular, Article 12 of the Directive provides private entities with the right, in certain circumstances, to request a competent authority to undertake action in relation to instances of environmental damage. Furthermore, Article 13 grants the same private entities the right to have

'access to a court or other independent and impartial public body competent to review the procedural and substantive legality of the decisions, acts or failure to act of the competent authority under the Directive itself'.

40 European Commission, Roadmap, Commission initiative on Access to justice in environmental matters at Member State level in the field of EU environment policy, p. 3.

41 Directive 2004/35/EC of the European Parliament and of the Council of 21 April 2004 on environmental liability with regard to the prevention and remedying of environmental damage [2004] OJ L143/56.

42 For an overview of the Environmental Liability Directive, see L. Bergkamp (ed), The EU environmental liability directive: a commentary (Oxford University Press 2013). 
Both rights of request to the competent authorities and of access to court against the authorities' conduct is subject to a standing test which, for the most part, reproduces the one contained in the Public Participation Directive. Indeed, Article 12(1) of the Environmental Liability Directive (which is referred to by Article 13 and thus is applicable also to the right of access to court), provides that natural or legal persons have standing to file a request to the authorities or to bring a claim before a court only if they can show sufficient interest in environmental decision-making relating to the damage or maintain the impairment of a right. Both tests of 'sufficient interest' and 'impairment of a right' are, similar to what is provided by the Public Participation Directive, to be interpreted according to the domestic legal system of the Member States.

In the same way as the Public Participation Directive, the Environmental Liability Directive affords a preferential status to NGOs, by stating that, when they meet the requirements set in national law, environmental NGOs are to be deemed as having sufficient interest or as having rights capable of being impaired. Unlike the Public Participation Directive, the Environmental Liability Directive affords standing in a third situation as well, namely to natural and legal persons who are affected or likely to be affected by environmental damage. This addition seems to set a lower threshold for access to court in general, although it has no consequences for NGOs which will therefore most likely still not be able to meet this requirement. They will have instead to rely on receiving standing on grounds of having sufficient interest or maintaining the impairment of a right.

It appears from this analysis that, unlike the Aarhus Convention (and the directives transposing it), the Environmental Liability Directive does not provide private parties with a judicial review avenue to directly seek legal review and redress against environmental damage caused or threatened by other private parties. Instead it provides them with rights only vis-à-vis public authorities. Apart from this difference, however, the Environmental Liability Directive provides for similar standing requirements for access to justice of NGOs and, mutatis mutandis, the same scope of review to be carried out by national courts (i.e. the 'procedural and substantive legality' threshold).

It is debatable whether the case law of the CJEU mentioned above on the scope of review and standing test for NGOs with regard to the Public Participation Directive should be considered applicable also to Article 13 of the Environmental Liability Directive, considering that there is no 'wide access to justice' requirement in the latter Directive (unlike the Public Participation Directive) nor is there any direct link between the Directive and the Aarhus Convention. In the same way, it could be argued that the lack of procedural provisions on costs in the Environmental Liability Directive renders the requirements of Ar- 
ticle 9(4) of the Aarhus Convention inapplicable to claims concerning alleged violations of this Directive.

However, the lack of an explicit link between the Environmental Liability Directive and the Aarhus Convention should not, it is submitted, be taken to imply that the Aarhus requirements are not applicable to procedural provisions concerning claims brought under this Directive. Firstly because, as has been convincingly argued, Article 13 states that the provisions of the Directive shall be without prejudice to 'any provisions of national law which regulate access to justice', including the Aarhus Convention, which is to be a considered a 'component' of national law for the purposes of Article 13(2), since all Member States have signed and ratified the Convention. ${ }^{43}$

For the same reason, it could be maintained that the lack of procedural provisions on costs does not exempt national procedural rules from complying with the requirements provided in Article 9(4) of the Aarhus Convention, given its applicability through the domestic law of the Member States. ${ }^{44}$ These considerations can equally be applied to the requirement set by the Aarhus Convention to provide for adequate and effective remedies.

What needs to be noted is that while the Aarhus Convention is binding on and applies equally to all the Member States within and outside the scope of application of EU law, the consequences of non-compliance still differ. It is indeed only in so far as Member States are bound by the Convention through their EU membership that specific EU-related consequences apply, such as the duty of consistent interpretation by national courts and the possibility to be taken before the CJEU by the Commission in infringement proceedings and ultimately be subject to financial penalties. Outside the scope of application of EU law, instead, Member States remain bound by the Convention requirements under international law, without any risk of prosecution for non-compliance apart from the non legally binding (though politically very relevant) opinions of the monitoring body set up under the Aarhus Convention, the Aarhus Compliance Committee.

One could, however, understand the Environmental Liability Directive as a measure, if not taken in explicit transposition of Article 9(3) of the Aarhus Convention, but at least falling within the scope of this latter provision. From this premise, one would be able to conclude that the 'wide access to justice' as

43 M. Hedemann-Robinson, 'EU Implementation of the Aarhus Convention's Third Pillar: Back to the Future over Access to Environmental Justice? Part 2' [2014/4] European Energy and Environmental Law Review, p. 161.

44 Ibid., p. 162. 
well as the costs requirements remain nevertheless applicable also to those national environmental measures falling within the scope of application of EU law. As a consequence, these requirements would be binding on the Member States to the extent that they constitute EU law obligations, including all the consequences deriving from them.

The Figure below provides a schematic overview of the procedural areas affected by the Environmental Liability Directive and the requirements set therein.

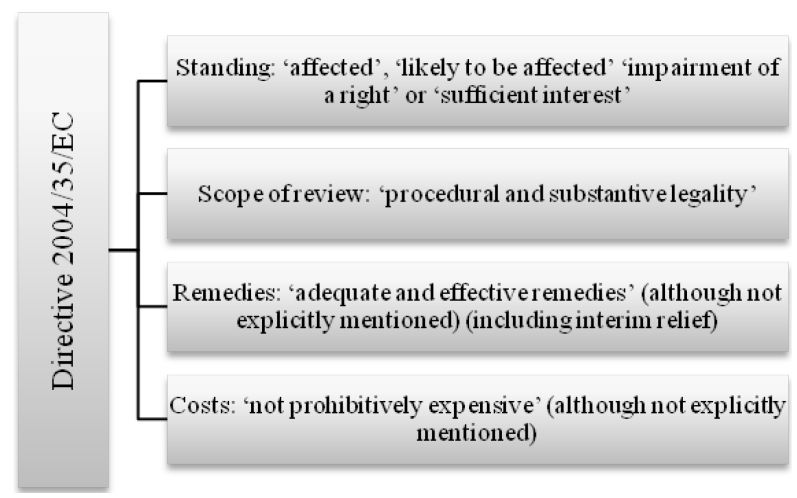

Figure 4: Schematic Overview of Procedural Areas Affected by the Environmental Liability Directive

\section{The 'State of Proceduralisation' of EU Environmental Legislation}

The picture sketched above shows, first of all, that the proceduralisation of environmental legislation is not the by-product of a comprehensive plan, but rather happened in a piecemeal fashion and in response to different needs.

The Aarhus Directives were enacted to respond to international pressures to comply with the requirements of the Aarhus Convention. While the need to comply with its international obligation was the primary drive behind the enactment of the procedural provisions contained in the Access to Information and the Public Participation Directive, it should not be overlooked that, around the time at which the directives were enacted, the Commission had explicitly shown its worries concerning the enforcement of EU environmental legislation at na- 
tional level ${ }^{45}$ and had specifically pointed to the inadequacy of national review procedures to sanction violations of EU environmental law. ${ }^{46}$

Subsequent to the signature of the Aarhus Convention, the EU has thus proceeded to take steps to implement the three pillars of this international instrument. As far as the access to justice pillar contained in Article 9 is concerned, the EU has, so far, only enacted secondary legislation to implement the first and second paragraph of this provision. The Access to Information and the Public Participation Directives provide for procedural provisions mandating certain requirements for claims by natural and legal persons complaining that their information or participation rights (respectively) have been violated by the public authorities.

As mentioned above, in line with the requirements of Article 9(1) of the Aarhus Convention, the Access to Information Directive essentially provides for a judicial review avenue with respect to access to information requests, and grants standing to those who applied for access to bring a judicial review claim. The court's review should cover the substantive and procedural legality of the authority's behaviour and the court's ruling is binding on the latter. Despite the applicability of Article 9(4) of the Aarhus Convention to access to information claims, rules on costs have formally remained outside the scope of the Access to Information Directive.

The Public Participation Directive goes even further into the procedural law of the Member States, by requiring a preferential standing status of standing for NGOs, a depth of review which would examine the procedural and substantive legality of national decisions falling within the scope of the participation requirements mandated by the Directive, and a 'not prohibitively expensive' judicial review procedure. Despite the vagueness of these requirements and the room for maneuver they leave to Member States, national procedural rules do need to comply with these standards and, as the case law of the CJEU (as

45 Report from the Commission to the European Parliament and the Council on the Application and Effectiveness of the EIA Directive (Directive 85/337/EEC as amended by Directive 97/11/EC): How successful are the Member States in implementing the EIA Directive? 23 June 2003 www.europa.eu.int/comm/environment/eia/report en.pdf.

46 Ibid., para. 4.8.2. An earlier report has raised the same concerns with regard to review procedures concerning access to environmental information requests. See Report from the Commission to the Council and the European Parliament on the experience gained in the application of Council Directive 90/313/EEC on freedom of access to information on the environment $\operatorname{COM}(2000) 400$ final, 29 June 2000 , p. 11. 
well as some studies) ${ }^{47}$ have shown, they do not always do, or at least they do so only after the CJEU's intervention. ${ }^{48}$

At the same time, the EU has failed to enact a comprehensive 'horizontal' measure which would implement Article 9(3) of the Convention and ensure access to justice for all kind of violations of EU environmental law. This means that wide sectors of EU environmental legislation, such as air quality, waste, water or noise have not been subject to any proceduralisation process (if one excludes the punctual intervention carried out by the CJEU). ${ }^{49}$ This means Member States remain completely free to set their own rules on standing, costs, intensity of review and possible remedies, subject only to the principles of equivalence, effectiveness and effective judicial protection as set out in the case law of the CJEU. Considering that the national rules transposing Article 9(3) of the Aarhus Convention have been labelled as 'diverging, random and inconsistent', ${ }^{\circ}$ the situation should be remedied with urgency as the current national differences may ultimately impair the possibility for national courts to control the violations of EU environmental law.

Despite the continuing gaps, it can be argued that the Aarhus Directives are an important step in the proceduralisation process of EU environmental legislation and they have certainly provided enhanced opportunities for NGOs to enforce EU environmental law, especially in legal systems such as the UK or Germany (as seen above) which for different reasons imposed a rather high threshold for access to justice in environmental matters. At the same time, it is to be hoped that the EU will complete its proceduralisation process through the enactment of an Access to Justice Directive which would cover all fields of environmental legislation and remove the differential treatment currently in place.

47 M. Eliantonio, C. Backes, C.H. van Rhee, T. Spronken \& A. Berlee, Standing up for your right(s) in Europe (Intersentia 2012), at Sections 4.7.4 and 4.10.1 (also available at www.europarl.europa.eu/committees/fr/studiesdownload.html?languageDocument= EN\&file=75651); S. Roussel and O. Fuchs, Accès Des Citoyens à La Justice et Organisations Juridictionnelles en Matière d'Environnement, Spécificités Nationales et Influences du Droit de l'union Européenne - Rapport, p.16-17. www.aca-europe.eu/seminars/Bruxelles2012/Rapport_general.pdf.

48 Both the Swedish and the German legislation which have been sanctioned by the CJEU in the case law mentioned above in footnote 14 have been amended in order to comply with the EU requirements. See further on this point, M. Eliantonio, 'Collective Redress in Environmental Matters: a Role Model or a "Problem Child”?’ [2014] Legal Issues of Economic Integration, p. 265266.

49 Case C-240/og Lesoochranárskezoskupenie VLKv. Ministerstv oživotného prostredia Slovenskej republiky [2011] ECR I-1255.

50 J. Darpö, Effective Justice? Synthesis report of the study on the Implementation of Articles 9.3 and 9.4 of the Aarhus Convention in Seventeen of the Member States of the European Union, p. 11. 
Without an explicit link to the Aarhus Convention, the Environmental Liability Directive also contains rules on the depth of review and on standing, which strongly mirror those of the Public Participation Directive. However this is without the clear caveat (contained in the Public Participation Directive) of the need for national procedural rules to ensure 'wide access to justice', or a requirement to provide for 'not prohibitively expensive' review procedures and for 'adequate and effective remedies'. The latter requirements could be considered as implied because of the need for national procedural rules to respect the provisions of the Aarhus Convention (as incorporated in their domestic legal systems). Alternatively, if one would consider the Environmental Liability Directive as an 'implicit' transposition of Article 9(3) of the Aarhus Convention, it would be possible to conclude that these could also constitute EU law requirements for all Member States' legal systems.

With the 2014 report of the Commission on the application of the Environmental Liability Directive still pending, ${ }^{51}$ it is too early to assess the full extent of the procedural provisions contained therein on the Member States' legal systems. However, it can safely be said that the procedural provisions contained in the Environmental Liability Directive provide a common minimum denominator which will enable NGOs to be more readily involved in situations of potential or actual damage (thanks to the preferential status afforded to them by the Directive) and grant them the possibility to ask the court to thoroughly review the conduct of public authorities with regard to this damage.

One final thought concerning the 'state' of proceduralisation of EU environmental legislation is whether, the procedural provisions discussed above have in effect brought about a higher intensity of procedural protection than has been and could be further achieved through the use of the principle of effective judicial protection (as developed by the case law of the Court of Justice of the European Union ${ }^{52}$ and currently also enshrined in Article 47 of the Charter of Fundamental Rights of the European Union). As is well known, the principle of effective judicial protection, acting as a limitation to the principle of national procedural autonomy, ensures, in combination with the principles of equivalence and effectiveness, that a minimum common denominator of judicial protection is upheld in the European Union national courts. Given the duty arising from the Simmenthal case law ${ }^{53}$ for national courts to set aside national procedural 
rules which do not ensure effective judicial protection to legal situations protected by EU law, one would be tempted to conclude that the 'proceduralisation' phenomenon did not deliver any additional protection for citizens against violations of EU environmental law by national authorities.

This conclusion would, however, overlook the fact that the scope and meaning of the principle of effective judicial protection are developed by the Court of Justice, whose intervention can only be of a case-by-case nature. This makes this approach dependent on the capacity of the litigants to obtain access to the national courts and on the willingness of the latter to cooperate. In addition, one should not underestimate the inevitable influence of the factual circumstances upon the principles enunciated by the CJEU, ${ }^{54}$ and the fact that the CJEU's analysis is necessarily limited to the procedural rules called into question by the national courts. This often implies that remedial rules that fall below the European standards of protection in a certain legal system may well be acceptable if examined in the context of another legal system which provides for mechanisms that compensate the 'shortcomings' of the rules in question.

Furthermore, the principle of effective judicial protection has to be applied by the judges in the Member States. This application may vary according to the judges' knowledge of, and sensitivity to, European issues ${ }^{55}$ with the European institutions, being without the tools to effectively control the application of these standards in a systematic way. ${ }^{56}$

\section{Conclusion}

Having analysed the state of proceduralisation of EU environmental legislation, it is possible to draw some conclusions and propose some recommendations.

First of all, the proceduralisation process of EU environmental law analysed above shows that, although a certain degree of harmonisation has been achieved through setting minimum standards to be respected by the procedural law of the Member States, some procedural differences remain. Notably, within the

54 M. Dougan, for example, concludes his book by stating that 'indeed, one might ultimately feel pressed towards the conclusion that remedial harmonisation [...] is a task to which the Court is inherently unsuited'. M. Dougan, National Remedies Before the Court of Justice. Issues of Harmonisation and Differentiation (Hart 2004), p.392.

55 In addition, one could add on the basis of the Köbler ruling, only in very exceptional circumstances could the national courts' disregard of EU law give rise to State liability.

${ }_{56}$ Apart from the limited option of pursuing the infringement through Article 258 TFEU procedure. 
framework established by the Aarhus Convention and the transposing directives as well as the Environmental Liability Directive, Member States remain free to set their own procedural rules on standing, costs of proceedings, scope of review and remedies. By way of example, while costs of proceedings may not be 'prohibitively expensive', Member States are free to set their own (potentially divergent) rules on costs. Beyond the requirements set by the European legislation, the principle of national procedural autonomy continues to apply, and covers for example the rules on time limits which are only subject to the requirements of CJEU case law on equivalence and effectiveness.

Given the potentially different outcomes which can be created by diverse national procedural rules, clearer procedural standards would probably eliminate the procedural differences which are currently in place, and which are within what is considered acceptable by the current procedural requirements. However, it is debatable whether the environmental legal basis (Article 192 TFEU) allows the EU institutions to legislate beyond what the Aarhus Convention requires and attempt to achieve a higher degree of harmonisation, and, at the same time, whether such an action would comply with the principles of subsidiarity and proportionality. In this respect, further research would be necessary to investigate whether the current, acceptable, procedural differences affect the actual chances of enforcement for NGOs and natural persons throughout the EU. Should this be the case, there would be an argument to use Article 192 TFEU by reasoning that differences in enforcement of EU environmental legislation hamper the achievements of the environmental objectives of the EU enumerated in Article 191 TFEU. ${ }^{57}$ However, the negotiation process leading up to the Access to Justice Directive shows that finding a minimum common denominator that fits in 28 systems of administrative justice is a very hard task. Moreover, such sectoral harmonisation could be considered ultimately detrimental to the national systems of administrative justice in general, as it would create a 'special' judicial avenue for environmental claims, thereby potentially endangering the overall coherence of the system.

Furthermore, the proceduralisation of EU environmental legislation can certainly offer some interesting lessons for other policy areas. First of all, the procedural provisions on costs introduced in the Public Participation Directive, though vague, do set a certain limit to procedural freedom in this area. Indeed, this kind of provision could be welcome in other EU policy areas, such as consumer or non-discrimination policies, where there can be potentially many

57 I.e. the preservation, protection and improvement of the quality of the environment, the protection of human health, the prudent and rational utilisation of natural resources and the promotion of measures at international level to deal with regional and worldwide environmental problems and in particular the combat of climate change. 
situations in which applicants may have a grounded claim, but may be discouraged from bringing it because of the costs connected to the proceedings.

Another important lesson to be learnt from the procedural provisions discussed above concerns standing requirements with preferential status for NGOs. The rationale for granting such standing is rooted in the special role they play in the enforcement of environmental law and in the idea of the environment as a 'common good' which belongs to everyone and no one at the same time. This rationale can similarly be applied to consumer and non-discrimination situations where there may be disenfranchised groups of applicants without the knowledge of the law, or the financial means to bring an individual suit. In such situations, an enhanced role for NGOs (through preferential standing rules before national courts) would certainly contribute to the achievement of the EU's objectives in these policy fields. 